\title{
EU Citizenship, Duties and Social Rights
}

\author{
Martin Seeleib-Kaiser
}

Social rights and EU citizenship have moved from the fringe to the centre of the political debate. Ferrera's proposals are timely and address important issues of this urgently needed political and academic debates.

Since the ratification of the Maastricht Treaty (1993) European Union citizenship has formally become a reality and citizens of European Union Member States are no longer only citizens of the respective Member States, but also 'multinational citizens' of the European Union. ${ }^{1}$ However, welfare states continue to be largely defined through nation-state borders, ${ }^{2}$ creating welfare state insiders and outsiders. Accordingly, EU migrant citizens ${ }^{3}$ are often considered as outsiders, who access social benefits and services without having fulfilled their duty of having paid taxes in the country of destination. This perception has led to a significant politicisation of freedom of movement and to the notion of 'welfare tourism' in a number of Member States.

Despite the at times dominant frame of 'welfare tourism', especially in the UK media, the main reason for intra-EU migration is work. Due to high employment rates among EU migrant citizens, it is not surprising that empirically there is no evidence of 'welfare tourism.' Moreover, various analyses have demonstrated that EU migrant citizens are net contributors in countries of destination, i.e. they contribute more in taxes and social (insurance) contributions than they

Aron, R. (1974), 'Is Multinational citizenship possible?', Social Research 41 (4): 638-656.

2 Ferrera, M. (2005), The Boundaries of Welfare. European Integration and the New Spatial Politics of Social Protection. Oxford: Oxford University Press.

3 I define EU migrant citizens as EU citizens who are, or intend to become, habitually resident in a Member State of which they do not hold nationality. This category differs from EU mobile citizens, i.e. citizens who move across borders for limited periods of time. EU citizens belonging to the category of mobile citizens fall into the subcategories of cross-border workers, posted workers, students or tourists. 
take out in benefits and services. ${ }^{4}$ As a group EU migrant citizens 'over-fulfil' their duty to contribute to funding welfare benefits and services in the Member State of destination. This obviously does not mean that every EU migrant citizen fulfils an individual duty. But, does this mean s/he should not be entitled to minimum income benefits or services? In this context it might be helpful to highlight that welfare states do not apply the principle of an individual duty to nationals or permanent residents as a precondition for receiving (subsistence) benefits or certain social services, such as health care. And there are good reasons not to do so!

Nevertheless, the significant increase in intra-EU migration has led to problems and challenges at the local and regional level putting pressure on social services. Ferrera suggests the establishment of a special EU fund to address these problems, while Joppke argues that such a fund would benefit those countries that already benefit from intra-EU migration. In my view, this debate seems rather academic, as EU funds to deal with challenges arising from intra-EU migration are already available under current EU funding arrangements. By using resources from the European Social Fund (ESF) and the Fund for European Aid to the Most Deprived (FEAD) affected local authorities and organisations, for instance in Germany and Sweden, were able to address some of the challenges arising from intra-EU migration at the local level. In other words, existing European funds can provide local actors with additional resources, without necessarily providing Member States that benefit from intra-EU migration with additional funds. No such funds were used in England to address the challenges in the localities most affected by intra-EU migration - a political choice by the UK government! For the future it would seem reasonable to increase the overall levels of the ESF or FEAD and making these funds more conditional upon addressing 'European' social issues (including the potential negative effects of intra-EU migration at the local level, be this in the countries of origin or destination), thereby strengthening EU social citizenship at the local level. ${ }^{5}$

4 Dustmann, C. \& T. Frattini (2014), 'The Fiscal Effects of Immigration to the UK', The Economic Journal 124 (580): F593-F643; Martinsen, D. S. \& G. P. Rotger (2017), 'The Fiscal Impact of EU Immigration on the Tax-financed Welfare State', European Union Politics 18 (4): 620-639, doi: https://doi. org/10.1177/1465116517717340.

5 Bruzelius, C, E. Chase \& M. Seeleib-Kaiser (2014), 'Semi-Sovereign Welfare States, Social Rights of EU Migrant Citizens and the Need for Strong State Capacities', Social Europe Journal, Research Essay No. 3, available at https:// www.socialeurope.eu/book/ re-no-3-semi-sovereign-welfare-states-social-rights-of-eu-migrant-citizensand-the-need-for-strong-state-capacities 
Another challenge associated with EU citizenship is the risk of exploitation in labour and housing markets. Job-seeking EU migrant citizens from Central and Eastern European as well as Southern Member States often cannot rely on substantive social rights, as the system of Social Security Coordination does not provide any substantive exportable unemployment benefits for them. As a consequence of residence requirements they are neither entitled to minimum income benefits in the country of destination, putting them at risk of exploitation. If one considers the concept of freedom of movement not only as a negative liberty, but also as a positive right, it would seem reasonable to introduce a European Minimum Income Scheme or a supra-national unemployment scheme, as suggested by Ferrera, to address the identified challenge of insufficient social security and risk of exploitation among job-seeking EU migrant citizens. ${ }^{6}$

Vandenbroucke suggests the introduction of an EU minimum wage, strengthening the ability of Member States to provide good and comprehensive social protection at the national level and reforming the existing arrangements for posted workers. These are laudable proposals, but they would seem largely ineffective to address the problems of potential exploitation among EU migrant citizens without substantive exportable unemployment benefits or insufficient social protection, especially since main destination countries, such as Britain and Germany, already have national minimum wage systems. It is the duty of Member States to enforce national and EU minimum standards in labour and social law to avoid social dumping and the undermining of national working conditions for this we do not need new regulation, but the enforcement of current laws! ${ }^{7}$ In this context it seems worthwhile to note that British authorities have only recently started to 'accept' the duty to enforce minimum wage and working conditions by appointing the UK's first labour market enforcement chief. ${ }^{8}$

Irrespective of the increasing importance of EU citizenship and social rights in the current political and academic debates, many participants still shy away from getting to the core of EU citizenship as a fundamental right. The issue of social rights and duties of EU migrant citizens within the EU is not sui generis, as it has been at the centre of many political and judicial debates in (con)federal jurisdictions. In this context it might be worthwhile

6 Bruzelius, C., C. Reinprecht \& M. Seeleib-Kaiser (2017), 'Stratified Social Rights Limiting EU Citizenship', Journal of Common Market Studies 55 (6): 1239-1253.

7 Bruzelius, C., E. Chase, E \& M. Seeleib-Kaiser (2014), see above.

8 Khan, M. 'UK appoints enforcer to crack down on minimum wage abuse', Financial Times, 17 January 2017, available at https:/www.ft.com/content/ b61d7370-d31e-11e6-9341-7393bb2e1b51. 
to learn from two historical examples: the North German Confederation (Norddeutscher Bund, NDB; 1867-1870) and the United States of America. Citizenship of these two jurisdictions was derived from the citizenship of the constituent states - very similar to EU citizenship. Furthermore, important elements of the welfare state, such as providing a minimum of subsistence or certain social services, were the responsibility of the constituent states. For Bismarck the system of local and regional poor relief with restrictive residence requirements was incompatible with the principle of freedom of movement in the NDB. Consequently, the Unterstützungswohnsitzgesetz (law on the domicile for social assistance) of 1870 entitled every poor person within the territory of the NDB to poor relief at the place of residence, irrespective of the Member State of origin and duration of residence. The US Supreme Court ruled against the State of California, which in the 1990s once again had introduced minimum residence requirements for the state welfare programme, declaring the residence clause as unconstitutional, arguing: 'Citizens of the United States, whether rich or poor, have the right to choose to be citizens of the State wherein they reside. ... The States, however, do not have any right to select their citizens' (Saenz v. Roe; 526 U.S. 489 (1999): 511)9.

For EU citizenship to become truly a fundamental status it is necessary to overcome the differentiation between economically active and non-active EU migrant citizens and finally abolish the residence requirements, as it was the case in the NDB and the US - territorial jurisdictions with isopolitical citizenship. Simply put: to be, or not to be, an EU citizen that is the question!

Open Access This chapter is licensed under the terms of the Creative Commons Attribution 4.0 International License (http://creativecommons.org/licenses/by/4.0/), which permits use, sharing, adaptation, distribution and reproduction in any medium or format, as long as you give appropriate credit to the original author(s) and the source, provide a link to the Creative Commons license and indicate if changes were made.

The images or other third party material in this chapter are included in the chapter's Creative Commons license, unless indicated otherwise in a credit line to the material. If material is not included in the chapter's Creative Commons license and your intended use is not permitted by statutory regulation or exceeds the permitted use, you will need to obtain permission directly from the copyright holder.

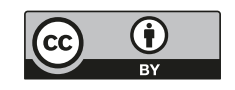

9 Bruzelius, C. \& M. Seeleib-Kaiser (2017), 'Freedom of Movement and the Right to a Minimum Income: Comparing the North German Confederation, the US and the EU', paper presented at the 2017 Annual Conference of the Research Committee 19, ISA, University of North Carolina, Chapel Hill, 22-14 June 2017. 